\title{
Dekomposisi Wavelet Data Seismik Broadband dari Stasiun Wanagama Yogyakarta pada saat Letusan Gunung Merapi 2010
}

\author{
Dairoh* dan Wiwit Suryanto \\ Laboratorium Geofisika, Program Pascasarjana Ilmu Fisika, \\ Universitas Gadjah Mada Kampus MIPA Sekip Utara, Bulaksumur, Sinduadi, Mlati Kota Yogyakarta, 55281
}

\section{Intisari}

Letusan Merapi 2010 mengakibatkan kerusakan alat pengamatan seismik yang terpasang disekitar gunung Merapi. Penelitian ini bertujuan untuk meneliti karakteristik gempa vulkanik gunung Merapi dari daerah di luar bahaya gunungapi (stasiun Wanagama). Analisis dilakukan dengan melakukan proses dekomposisi wavelet untuk memisahkan event gempa vulkanik dan noise yang terekam selama kurun waktu letusan gunung Merapi 2010. Proses dekomposisi dilakukan dengan menggunakan wavelet Daubechies orde 5. Intrepretasi dilakukan dengan melihat karaktersitik sinyal gempa vulkanik dengan kandungan frekuensi sinyal hasil dekomposisi tersebut. Dari hasil penelitian ini diperoleh informasi event gempa vulkanik yang terjadi selama letusan Merapi 2010.

\section{ABSTRACT}

Eruption of mount Merapi in 2010 has caused damaged the seismic observation stations installed around mount Merapi. This research aimed to investigate the characteristics of Mount Merapi is volcanic earthquakes of the outside of volcanoes danger area(Wanagama station). The analysis was conducted by wavelet decomposition process to separate the noise volcanic and seismic events were recorded during the period of the eruption of Mount Merapi, 2010. The decomposition process was done by using wavelet Daubechies order of 5 . The interpretation was made by looking at the characteristics of volcanic seismic signals with frequency content of the signal decomposition. From the results, the research shows event of volcanic earthquakes that occurred during the 2010 eruption of Merapi.

KATA KUNCI: daubechies, eruption of Merapi 2010, wavelet decomposition, earthquake volcanic http://dx.doi.org/10.12962/j24604682.v13i2.2157

\section{PENDAHULUAN}

Gunung Merapi terletak di persimpangan antara dua jalur vulkanik utama yaitu gunung Ungaran Telomoyo-MerbabuMerapi (utara ke selatan) dan gunung Lawu - Merapi - Sumbing - Sindoro - Slamet (timur ke barat). Diantara gunungapi tersebut, gunung Merapi memiliki umur yang termuda. Secara tektonik gunung Merapi terletak di atas zona subduksi antara lempeng tektonik Australia dan Eruasia [1].

Merapi mulai menunjukkan aktivitas setelah aktivitas terakhirnya pada 2006 yaitu pada bulan September 2010. Secara umum gunungapi tersebut memiliki interval erupsi dalam kurun waktu 2-5 tahun sekali. Pada tanggal 20 September 2010 Pusat Vulkanologi dan Mitigasi Bencana Geologi (PVMBG) menaikkan status Merapi menjadi waspada. Minggu pertama setelah ditetapkan statusnya menjadi waspada, aktivitas Merapi secara perlahan namun pasti terus meningkat [2].

Merapi masih berada pada fase fluktuatif yang ditandai dengan naik turun aktivitas vulkaniknya dan kondisi Merapi berubah cepat. Sejak Tanggal 10 Oktober 2010, deformasi Merapi terus mengalami peningkatan secara drastis [3].

*E-MAIL: zaroh31@yahoo.co.id
Pada stasiun Balai Penyelidikan dan Pengembangan Teknologi Kegunungapian (BPPTK) saat letusan Merapi 2010. Hasilnya pada tanggal 4 November 2010 aliran piroklastik gunung Merapi mengalir sampai dengan jarak 12 $\mathrm{km}$ dengan amplitudo yang dihasilkan dua kali lebih tinggi dibandingkan dengan amplitudo pada tanggal 3 November 2010. Penelitian tersebut hanya melakukan analisis pada pergerakan aliran piroklastiknya [4].

Menurut BPPTK, kondisi Merapi semakin menunjukkan perubahan aktivitasnya. Letusan gunung Merapi 26 Oktober 2010 adalah letusan dengan rentang waktu erupsi yang lama, hal ini menyebabkan kerusakan pada stasiun pengamatan seismik yang terpasang di sekitar gunung Merapi. Adanya dampak kerusakan terhadap alat-alat pengukuran seismik di stasiun pengamatan gunung Merapi maka dilakukan studi terhadap gempa vulkanik gunungapi dari jarak yang jauh tepatnya di daerah yang termasuk diluar bahaya $( \pm 45 \mathrm{~km})$ dari gunungapi, yaitu di stasiun Wanagama UGM. Data dari rekaman stasiun Wanagama tersebut dilakukan analisis terhadap fitur karakteristik dari sinyal seismik dengan dekomposisi wavelet untuk memisahkan event gempa vulkanik, tektonik dan derau (noise).

Pada penelitian ini dilakukan dekomposisi wavelet terhadap data rekaman seismik broadband di stasiun Wanagama dengan menggunakan dekomposisi wavelet Daubechies orde 
5 level 5. Dalam dekomposisi berbasis wavelet akan mengurai sinyal seismik broadband dan diperoleh sinyal-sinyal yang memiliki perubahan yang tajam dan tampak lebih smooth. Tujuan dari penelitian ini adalah mengkarakteristik sinyal dari hasil dekomposisi wavelet untuk gempa vulkanik sehingga diketahui aktivitas gempa vulkanik selama letusan gunungapi.

Dari penelitian ini diharapkan dapat diketahui karakteristik sinyal serta aktivitas gempa vulkanik dari data rekaman seismik di stasiun yang terletak di luar daerah bahaya letusan gunungapi.

\section{LANDASAN TEORI}

\section{Gempa Vulkanik}

Aktivitas gempa vulkanik pada gunungapi umumnya dibedakan menjadi dua, yaitu aktivitas di luar gunungapi berupa gugurnya kubah lava, keluarnya uap, aliran lava dan awan panas (pyroclastic flow) dan aliran lahar. Aktivitas internal yaitu adanya kegempaan yang disebabkan oleh bermacam-macam mekanisme seperti gesekan bidang rekahan batuan tubuh gunungapi dan kerusakan geser (shear failure) akibat dari tekanan geser atau kompresi, traction pada dinding reservoir (magma chamber) [5]. Berdasarkan sumber dan perilakunya menurut Minakami [6] gempa vulkanik dibagi menjadi 5 macam, yaitu:

1. Gempa vulkanik tipe A atau gempa dalam, terjadi pada kedalaman 1 hingga dengan $2 \mathrm{~km}$. Gempa ini mempunyai frekuensi tinggi, yaitu antara 5-8 Hz. Impuls pertama cukup jelas. Pada gunung Merapi gempa ini sangat jarang terjadi, biasanya mengawali siklus kegiatan letusan. Jenis gempa ini dibedakan fase gelombang $\mathrm{P}$ dan $\mathrm{S}$ terpisah cukup jelas, S-P time lebih besar dari 0,5 detik [7]

2. Gempa vulkanik tipe B, terjadi pada kedalaman gempa kurang dari $2 \mathrm{~km}$, dengan impulse pertama cukup jelas walaupun kadang-kadang emergent. Frekuensi gempa sekitar 4-7 Hz, dengan fase gelombang P dan S tidak terpisah secara jelas klasifikasi gempa tipe $\mathrm{B}$ gunungapi [8] menjadi 4 tipe, yaitu;

- HF (B), merupakan gempa vulkanik B dengan waktu tiba gelombang P yang jelas.

- LHF, yaitu gempa gabungan dari gempa frekuensi rendah (LF) dan gempa frekuensi tinggi (HF).

- LF, yaitu gempa vulkanik dangkal dengan frekuensi sekitar $1,5 \mathrm{~Hz}$ dengan waktu tiba cukup jelas. Amplitudo gempa ini sangat kecil.

- MP atau multiphase, merupakan gempa vulkanik dangkal. Bentuk sampul gempa ini nampak seperti gempa vulkanik B, frekuensi berkisar antara 3-4 Hz. Gempa MP banyak terjadi pada saat terjadi pertumbuhan kubah lava.

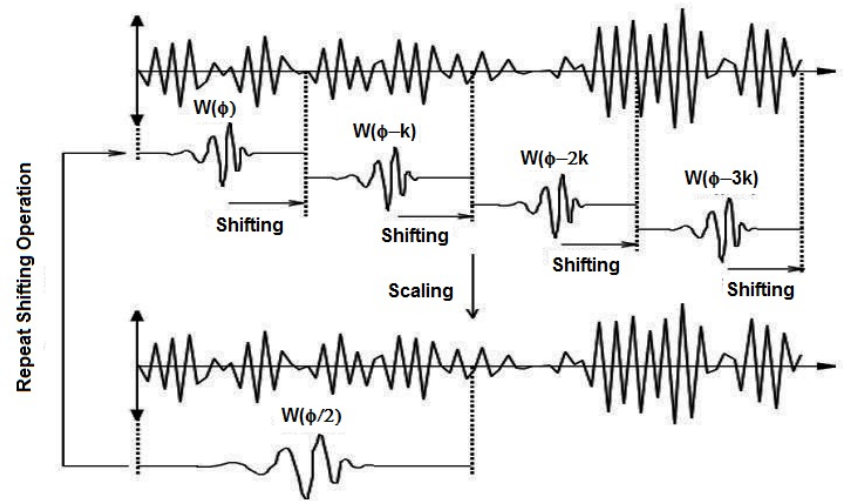

Gambar 1: Proses penskalaan dan pergeseran dalam transformasi wavelet $[10]$.

3. Tremor vulkanik, gempa yang disebabkan oleh aktivitas fluida magma. Bentuk dari gelombang dari tremor adalah impulsif dan merupakan gelombang stasioner. Gempa tremor gunung Merapi mempunyai frekuensi sekitar $0,7-1,5 \mathrm{~Hz}$, dengan durasi dalam orde menit sampai jam.

4. Gempa hybrid, gempa yang sejenis dengan gempa tipe $\mathrm{B}$, mempunyai amplitudo yang pendek dan saling susul menyusul.

5. Guguran kubah lava atau muncul aliran awan panas (piroklastik mempunyai amplitudo yang tinggi dan turun secara transien).

\section{Transformasi Fourier}

Transformasi Fourier merupakan metode untuk menentukan kandungan frekuensi dari sebuah sinyal. Transformasi Fourier pada dasarnya membawa sinyal dari dalam kawasan waktu (time-domain) kedalam kawasan frekuensi (frekuensidomain). Hasil dari transformasi Fourier adalah distribusi densitas spektral yang mencirikan amplitudo dan fase dari beragam frekuensi yang menyusun sinyal [9]. Persamaan transformasi Fourier dapat dituliskan sebagai berikut:

$$
H(f)=\int_{\propto \propto}^{\propto} h(t) e^{2 \pi i f t} d t
$$

dengan $\mathrm{H}(\mathrm{f})=$ fungsi dalam kawasan frekuensi, $\mathrm{h}(\mathrm{t})=$ fungsi dalam kawasan waktu, $\mathrm{t}=$ waktu (sekon), $\mathrm{f}=$ frekeunsi $(\mathrm{Hz})$

\section{Transformasi Wavelet}

Transformasi wavelet merupakan transformasi yang melokalisasi waktu dan frekuensi secara simultan. Transformasi wavelet digunakan untuk melihat perubahan frekuensi dalam sinyal terhadap waktu. Hasil dari transformasi wavelet berupa representasi sinyal dalam kawasan waktu dan frekuensi. Transformasi wavelet akan menguraikan suatu sinyal dalam bentuk suku-suku wavelet dengan menggunakan 


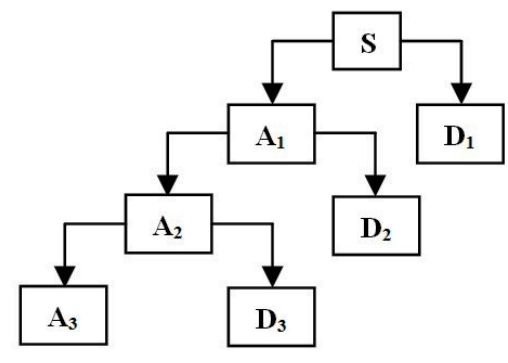

Gambar 2: Pohon dekomposisi wavelet 3 tingkat.
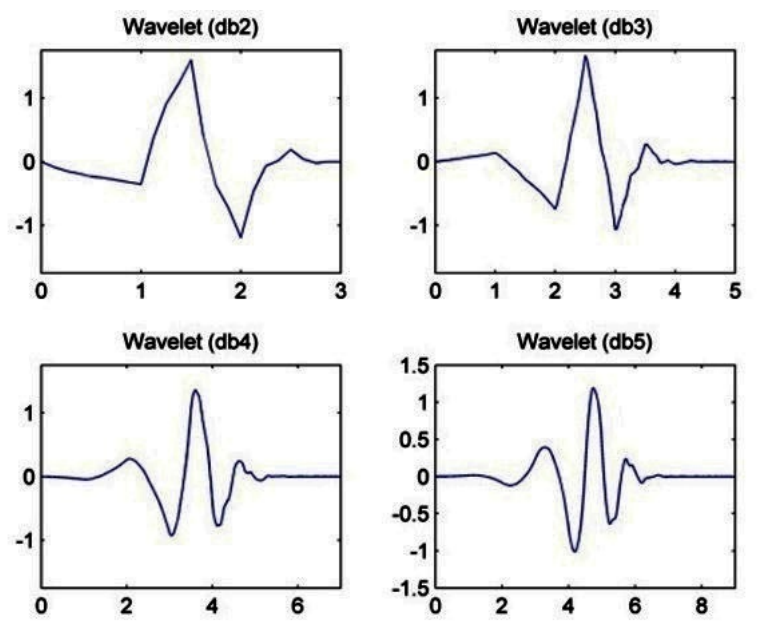

Gambar 3: Menunjukkan fungsi keluarga wavelet Daubechies pada ke $\mathrm{N}$-orde.

fungsi pergeseran (translation) dan penskalaan (scaling) yang tersaji seperti pada Gambar 1.

Transformasi wavelet dari sebuah fungsi runtun waktu $\mathrm{f}(\mathrm{t})$ didefinisikan dalam bentuk integrasi [11]. Persamaan transformasi wavelet adalah

$$
W_{f(u, s)}=\left(f, \Psi_{u, s}\right)=\int_{\propto \propto}^{\propto} f(t) \frac{1}{\sqrt{s}} \Psi^{\star}\left(\frac{t-u}{s}\right) d t
$$

\section{Dekomposisi wavelet}

Transformasi wavelet mendekomposisi sinyal $\mathrm{x}(\mathrm{t})$ kedalam bentuk varian sinyal induk wavelet yang terdilatasi dan tertranslatasi. Dalam sinyal seismik, transformasi wavelet akan mengguraikan suatu seismogram kedalam unsur-unsur pokok gelombang yaitu amplitudo, fase dan frekuensi. Sebuah sinyal didekomposisi menjadi bagian aproksimasi dan detil, kemudian bagian aproksimasi ini dibagi lagi menjadi tingkat-kedua aproksimasi dan detil, proses ini diulang-ulang. Untuk n-tingkat dekomposisi akan terdapat $\mathrm{n}$ kemungkinan hasil dekomposisi sinyal, dibagian filter rekontruksi, tersaji pada Gambar 2.

Pada Gambar 2 dapat dituliskan persamaan

$$
\begin{aligned}
S & =A_{1}+D_{1} \\
& =A_{2}+D_{2}+D_{1} \\
& =A_{3}+D_{3}+D_{2}+D_{1}
\end{aligned}
$$

\section{Wavelet Daubechies}

Daubechies adalah salah satu jenis mother wavelet. Mother wavelet ini ditemukan oleh Ingrid Daubechies, seorang yang ahli dalam bidang penelitian wavelet, menemukan pendukung wavelet dan membuat analisis wavelet yang dapat dipraktekkan. Penamaan keluarga filter wavelet Daubechies ditulis $\mathrm{dbN}$, dengan $\mathrm{N}$ adalah orde maka wavelet Daubechies yang memiliki panjang filter $2 \mathrm{~N}$ dan db adalah nama panggilan dari wavelet (keluarga wavelet) [12]. Karakteristik umum filter wavelet Daubechies adalah wavelet ini memiliki jumlah vanishing moment paling tinggi untuk lebar yang ditentukan. Vanishing moment menunjukan kemampuan wavelet dalam merepresentasikan sifat polinomial, yang dimiliki oleh wavelet akan berpengaruh dalam penentuan jumlah koefisien filter wavelet. Semakin besar jumlah filter yang dimiliki oleh suatu wavelet filter Daubechies, maka semakin baik filter tersebut dalam melakukan pemilihan frekuensi, seperti terlihat pada Gambar 3.

\section{DATA DAN METODE}

Data yang gunakan dalam penelitian ini adalah data seismik rekaman seismometer 3 broadband STS-2 dari stasiun Wanagama yaitu pada komponen Z (vertikal) saja. Data seismik yang digunakan adalah data rekaman pada tanggal 26 Oktober dan 3 November 2010 serta data sekunder gempa tektonik dari tanggal 1 Oktober hingga 10 November 2010 yang diperoleh dari katalog BMKG dan data aktivitas gempa vulkanik berdasarkan katalog dari PVMBG.

Peralatan yang digunakan terdiri dari perangkat keras dan perangkat lunak, antara lain:

1. Komputer (PC) atau laptop, yang digunakan untuk menjalankan program.

2. Matlab R2006a, yang digunakan untuk melakukan proses pengolahan dan analisis data seismik, Toolbox signal processor dan Toolbox Wavelet.

3. Google earth, yang digunakan untuk membuat peta lokasi gunungapi, letak stasiun, letak gempa tektonik dan membuat peta penyebaran gempa tektonik terhadap stasiun rekaman.

4. Microsoft Excel 2007, yang merupakan program komputer yang digunakan untuk menghitung nilai azimuth dan episenter, membuat analisis grafik pada jumlah aktivitas gempa vulkanik.

Prosedur penelitian ditunjukkan Gambar 4. 


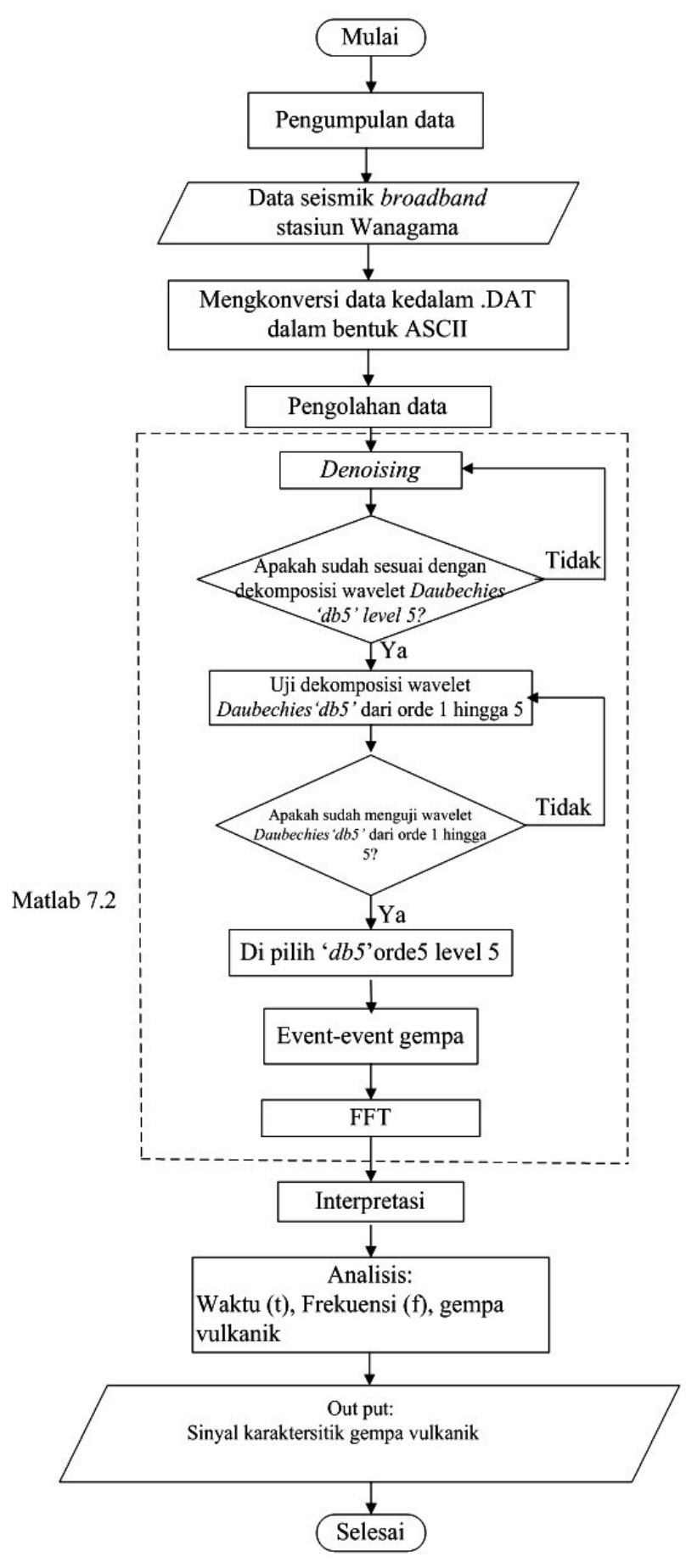

Gambar 4: Diagram alir pengolahan data.

\section{HASIL DAN DISKUSI}

\section{Analisis Gempa Tektonik}

Selama rentang terjadinya letusan gunung Merapi tercatat ada 21 kejadian gempa tektonik. Untuk mengetahui kandungan frekuensi dari gempa tektonik tersebut dilakukan analisis
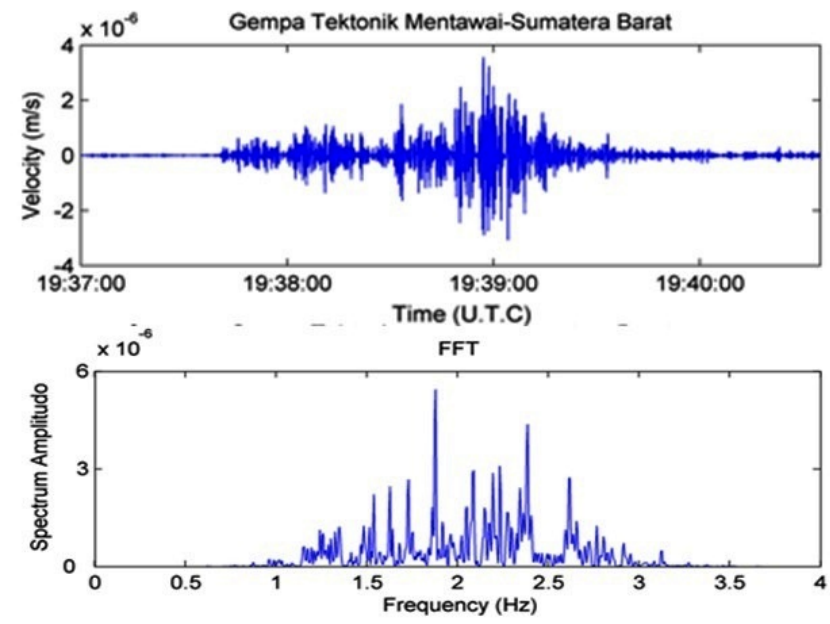

Gambar 5: Contoh hasil analisis FFT untuk gempa tektonik 26 Oktober 2010 .
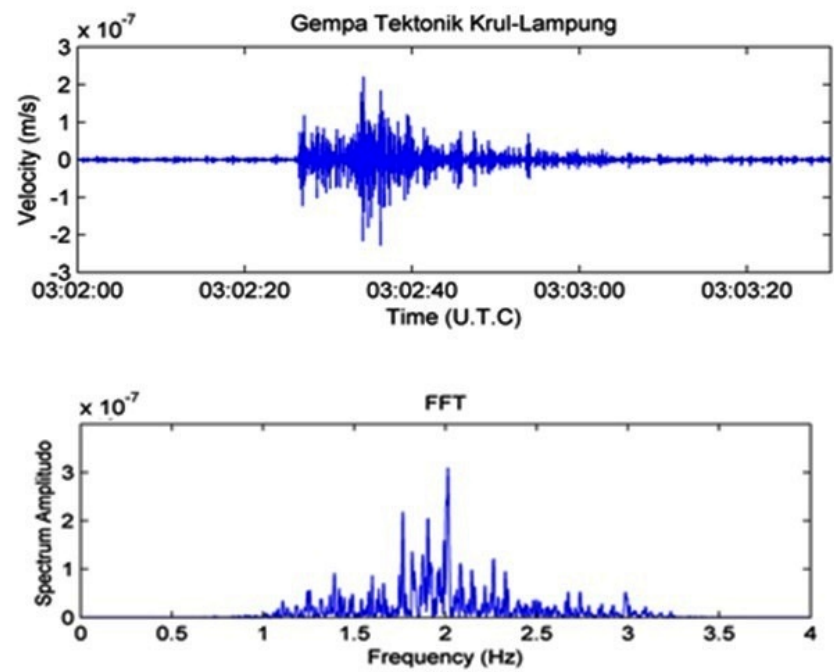

Gambar 6: Contoh hasil analisis FFT untuk gempa tektonik 3 November 2010.

menggunakan transformasi fourier pada tanggal 26 Oktober 2010 dan tanggal 10 November 2010, hasilnya telihat dalam Gambar 5 dan Gambar 6.

Pada Gambar 5, terekam sinyal seismik gempa tektonik berskala magnitude 6,2 SR, terjadi pada tanggal 26 Oktober 2010 di Pagai Selatan Mentawai Sumatera Barat, pukul 19:40 UTC dan kandungan frekuensi 0,88-3,14 Hz. Gambar 6 menunjukkan bahwa terjadi gempa tektonik pada tanggal 3 November 2010 di daerah Krul Lampung dengan skala magnitude 5.5 SR pukul 03:04 UTC dan kandungan frekuensinya 0,89-3,26 Hz.

\section{Analisis gempa vulkanik}

Hasil dekomposisi wavelet Daubechies, orde 5 level 5 dari data seismik, terlihat pada Gambar 7 dan Gambar 8 . 


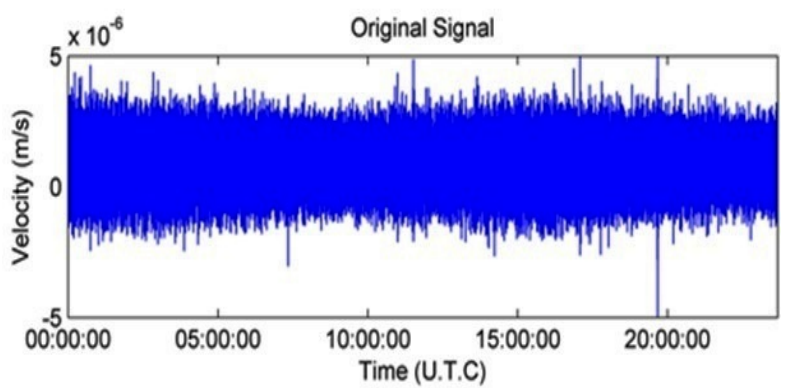

(a)

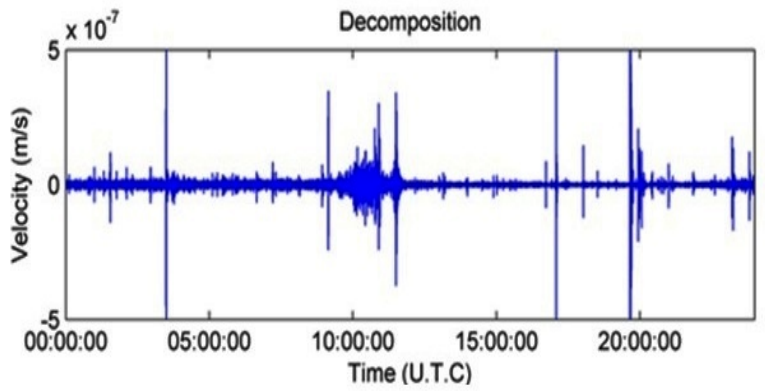

(b)

Gambar 7: Contoh rekaman (a). data seismik pada tanggal 26 Oktober 2010 pada saat letusan Merapi yang kedua (komponen vertikal), (b). sinyal dari gempa vulkanik yang diperoleh hasil menggunakan dekomposisi wavelet Daubechies.

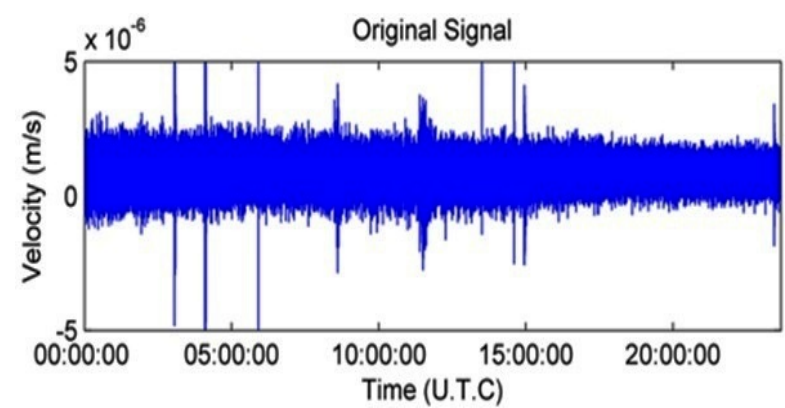

(a)

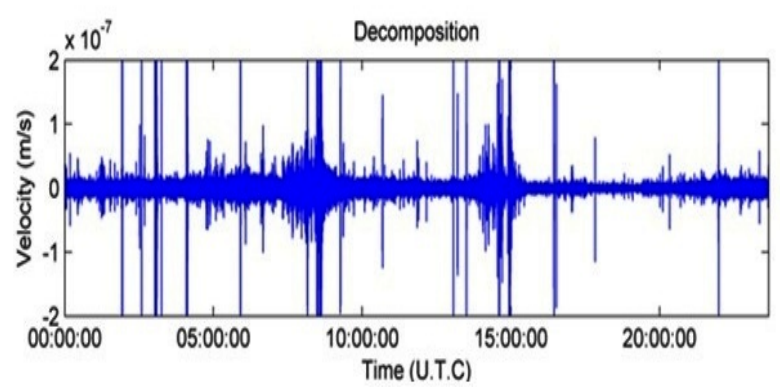

(b)

Gambar 8: Contoh rekaman (a). data seismik pada tanggal 3 November 2010 pada saat letusan Merapi yang kedua (komponen vertikal), (b). sinyal dari gempa vulkanik yang diperoleh hasil menggunakan dekomposisi wavelet Daubechies.
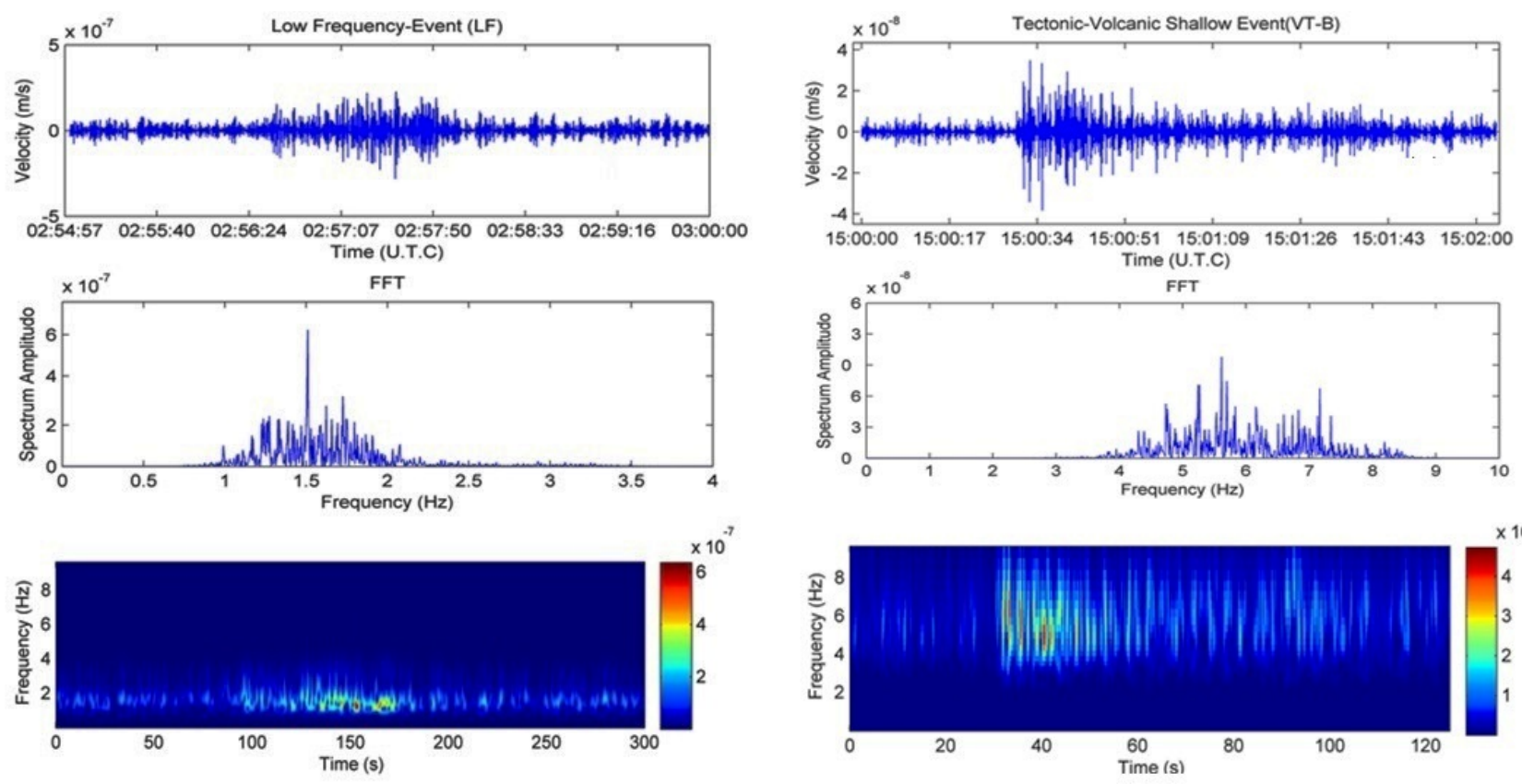

(a)

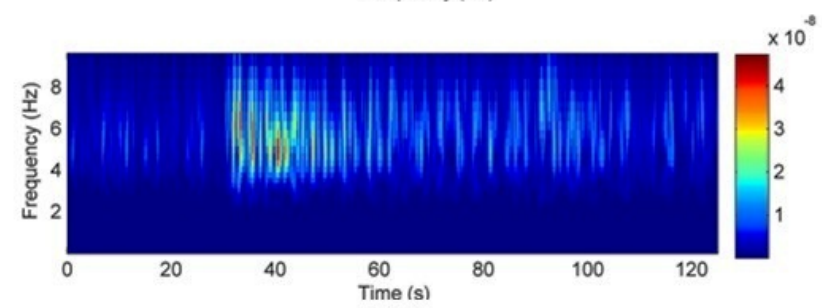

(b)

Gambar 9: (a). Karakteristik sinyal low frequency pada letusan gunung Merapi 26 Oktober 2010, (b). Karakteristik sinyal gempa vulkanik dangkal (VB) pada letusan gunung Merapi 26 Oktober 2010. 

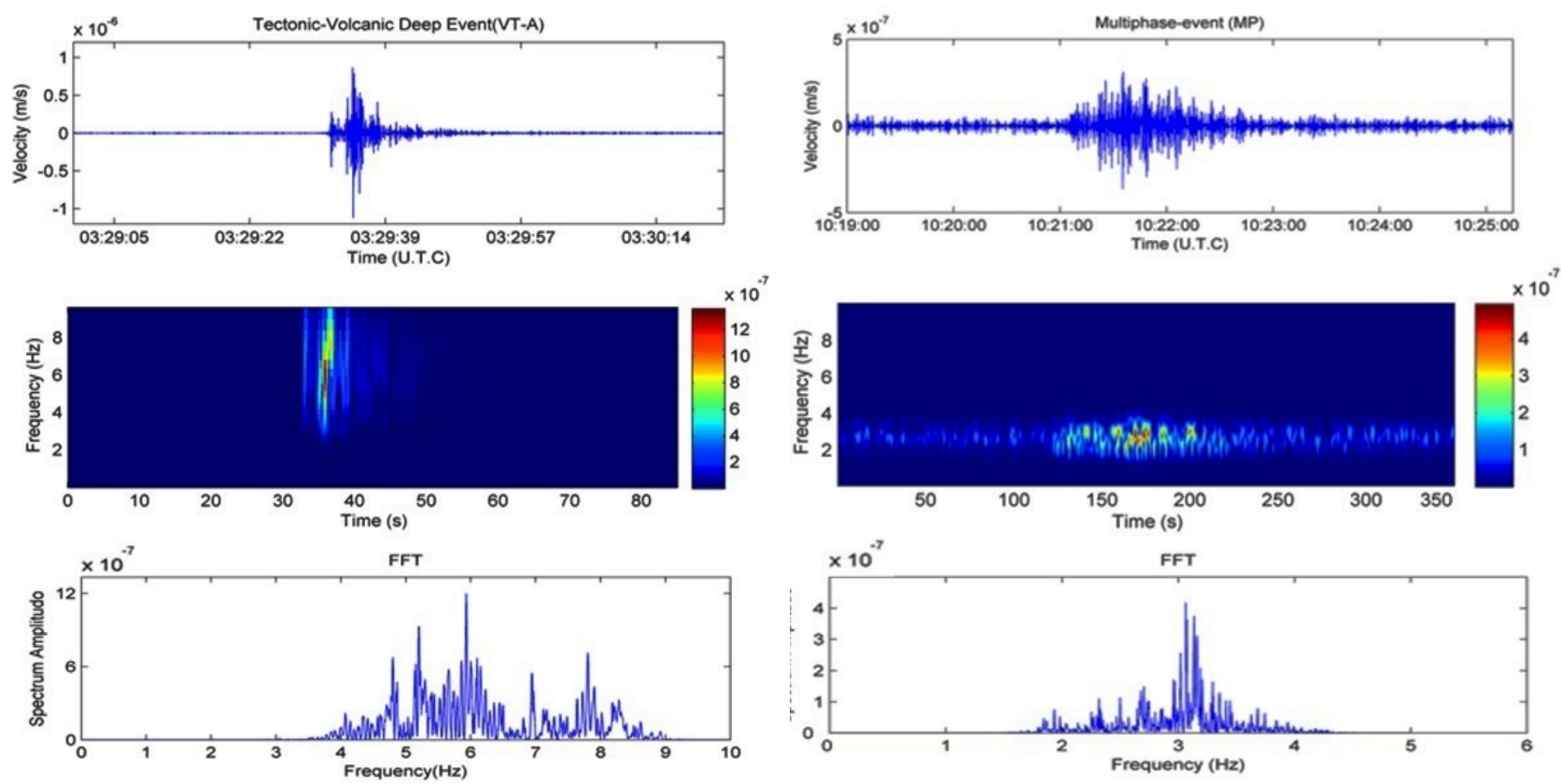

(a)

(b)
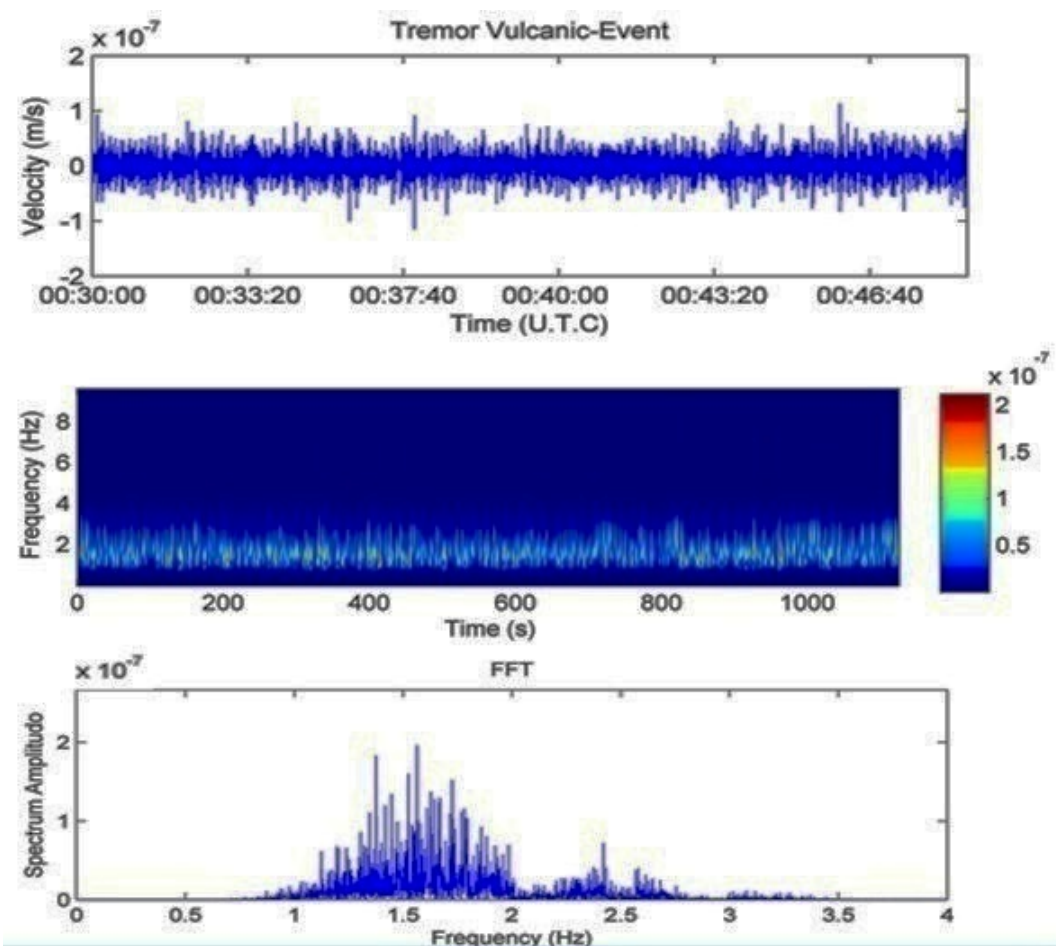

(c)

Gambar 10: (a). Karakteristik sinyal gempa vulkanik dalam (VA) pada letusan gunung Merapi 26 Oktober 2010, (b). Karakteristik sinyal multiphase pada saat letusan gunung Merapi 3 November 2010, (c). Karakteristik sinyal gempa tremor vulkanik pada letusan gunung Merapi 3 Oktober 2010.

Terlihat pada kedua gambar bahwa sinyalnya dekomposisi tampak lebih smooth dan terlihat segment-segment eventnya, untuk mengetahui karakteristik sinyal vulkaniknya dilakukan pemotongan terhadap segmen-segmen dan dilakukan analisis FFT untuk mengetahui kandungan frekuensinya, hasil karak- teristik event gempa vulkaniknya terlihat pada Gambar 9 dan Gambar 10. 


\section{SIMPULAN}

Hasil penelitian ini bahwa dari hasil dekomposisi wavelet diperoleh karaktersitik sinyal seismik gempa vulkanik yang terekam di stasiun Wanagama saat letusan Merapi 2010 yaitu gempa vulkanik dangkal (VB), gempa vulkanik dalam (VA), gempa frekuensi rendah (LP), gempa multiphase (MP), dan gempa vulkanik tremor.

\section{Ucapan Terima Kasih}

Peneliti mengucapkan terimakasih kepada pengelola program sekolah pasca sarjana UGM, pengelola Laboratorium Geofisika UGM dan Prof. Dr. Kirbani Sri Brotopuspito yang telah memberikan kepercayaan pada peneliti untuk dapat meneliti penelitian tersebut.
[1] R.W. Van Bemmelen, The Geology of Indonesia (V.IA, General Geology Government Publisher, The Hque, 1949).

[2] http://merapi.bgl.esdm.go.id/ diakses 12 Oktober 2011.

[3] A. Solikhin, H. Gunawan, S. Surono, P. Jousset, Volcanic Tremor Analysis During Merapi 2010 explosion Sequences, Geophysical Research Abstracts Vol.13, EGU2011-13937 (2010).

[4] -, Letusan Merapi 2010, Sebuah Catatan Jurnalistik, Harian Umum SoloPos \& Harian Jogja, Yogyakarta(2010).

[5] S.R. McNutt, Seismic Monitoring and Eruption Forecasting of Volcanoe:A Riview pf the State of the art and case Histories, in R. Scarpa, and R.I. Tilling (eds), Monitoring and Mitigation of Volcano, Montserrat, Geophys Res.Let., 25(18), 3401-3404 (1996).

[6] T. Minakami, Sesimology of volcanoes in japan (Elseveir scientific pubsling Company, Amsteram-Oxford-New York, 1974).

[7] A.R. Fadeli, Location of Seismic Source of Merapi (Central Java) with Implusive character, Scientifific Series of Interna- tional Bureau, 4, 137-148 (1990)

[8] J. Wasserman, Volcano Seismology, New Manual of Seismology Observatory Practice, Bulletin of IASPEI, 1 (2002).

[9] K. Enggar, Analisis Penampang Seismik 2-d dengan Menggunakan Atribut Seismik Berbasis Transformasi Wavelet Kontinyu dan Singularitas Data Seismik Migrasi, Skripsi, F-MIPA Universitas Gadjah Mada, Yogyakarta, 2005.

[10] R. Polikar, Tutorial of the Wavelet Theory (Second Edition, Department of Electrical and Computer Engineering, Rowan University, 1996).

[11] I. Daubechies, Ten Lecture on Wavelet (SIAM, Philadelphia, 1992).

[12] Novamizanti, Ledya, Identifikasi Pola Iris Mata Menggunakan Dekomposisi Transformasi Wavelet dan Levenshtein Distance, IT Telkom, Bandung, 2009. 